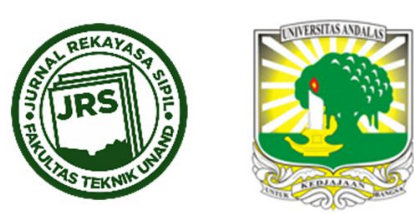

\title{
KERENTANAN KAWASAN PERMUKIMAN RAWAN BANJIR KAMPUNG KOLAM KELURAHAN TANJUNGPINANG BARAT TANJUNGPINANG
}

\author{
RIAN ROBIANTO ${ }^{1}$, MUSSADUN $^{1^{*}}$ \\ ${ }^{1}$ Magister Perencanaan Wilayah dan Kota, Fakultas Teknik, Universitas Diponegoro \\ *Corresponding author: $₫$ mussadun@pwk.undip.ac.id
}

Naskah diterima : 22 Desember 2019. Disetujui: 7 April 2020

\begin{abstract}
ABSTRAK
Tanjungpinang Barat adalah salah satu kelurahan pesisir yang sering dilanda banjir. Sebanyak $80 \%$ dari kawasan permukimannya selalu tergenangi air karena kawasan tersebut memiliki kontur yang lebih rendah dari daerah sekitarnya. Kawasan Kampung Kolam, Jalan Sulaiman Abdullah memiliki keterpaparan genangan air hingga lebih dari satu meter. Penelitian ini dilakukan untuk mengetahui tingkat kerentanan masyarakat dikawasan banjir sehingga dapat menjadi pertimbangan dalam penanganannya. Pendekatan yang digunakan adalah konsep kerentanan IPCC yaitu Exposure, Sensitivity, Capacity Adaptive karena dinilai lebih sesuai dengan karakteristik bencana yang terjadi. Penilaian tingkat kerentanan dilakukan secara kuantitatif dengan Weighted And Scoring Analisys. Dari hasil analisis temukan bahwa dari 80 responden rumah tangga terdapat sembilan responden yang berada pada kuadran tiga, dua responden berada pada kuadran empat dan enam puluh sembilan responden berada pada kuadran lima. Hal tersebut menunjukan 11,25\% responden memiliki tingkat kerentanan sedang kemudian 2,5\% responden memiliki kerentanan tinggi dan 86,25\% responden memiliki kerentanan yang sangat tinggi. Dari hasil penilaian diatas dapat disimpulkan bahwa kerentanan yang terjadi di masyarakat Kampung Kolam telah berada pada tingkat yang sangat tinggi, namun hal tersebut tidak membuat masyarakat untuk pindah ke tempat yang lebih aman dan memilih untuk tetap bertahan serta berupaya untuk beradaptasi dengan ancaman yang datang. Adaptasi yang dilakukan cenderung dengan melakukan peninggian bangunan, membuat tanggul pembatas di pintu rumah dan melakukan peninggian terhadap barang furnitur di rumah masing masing. Adapun penanganan kawasan yang direkomendasikan adalah peremajaan kawasan pada RT.03/RW.06 dan RT.05/RW.07 dan pemugaran kawasan pada RT.02/RW.06, RT.05/RW.06, RT.03/RW.07, RT.04/RW.07. Sedangkan penanganan kawasan dengan pendekatan adaptasi dilakukan peningkatan kapasitas komunitas maupun individu dalam penguatan perekonomian dan pendapatan, pendidikan, kelembagaan yang aktif hingga pengembangan sistem peringatan banjir skala kawasan.
\end{abstract}

Kata kunci : Banjir, Kerentanan, Kuantitatif, Scoring

\section{PENDAHULUAN}

Wilayah pesisir merupakan daerah yang memiliki potensi pemanfaatan yang cukup tinggi (Hapsari, Rustiadi, \& Yulianda, 2017). Wilayah pesisir juga menjadi kawasan tumpuan DOI : https://doi.org/10.25077/jrs.16.1.25-37.2020 
untuk menerima berbagai tekanan yang lebih tinggi dari wilayah lainnya (Yulia, 2014). Kawasan ini juga sangat rentan terhadap ancaman dari lingkungan ataupun bencana (Diposaptono, 2003), oleh karena itu dalam pengembangan dan pemanfaatan kawasan pesisir tanpa pengendalian dan arahan yang tepat akan mengganggu keseimbangan dan keberlanjutan lingkungan baik lingkungan binaan maupun lingkungan alami kawasan tersebut (Sulistyanto, 2017). Berbagai potensi kawasan pesisir ini menjadikan kawasan tersebut menjadi sangat strategis sehingga membuat kawasan tersebut sering kali berubah menjadi kawasan permukiman, pusat perdagangan hingga pusat pemerintahan. Sejalan dengan pertumbuhan penduduk fungsi permukiman menjadi lebih dominan tanpa memperhitungkan karakter geofisik dan klimatologi di pesisir. Salah satu faktor yang menyebabkan terjadinya perubahan guna lahan adalah pertumbuhan populasi dan peningkatan kebutuhan ruang kota (Ghozali, Ariyaningsih, Sukmara, \& Aulia, 2016). Selain potensi pemanfaatan kawasan terdapat juga potensi bencana yang selalu mengintai di kawasan pesisir. Bencana yang kerap terjadi pesisir antara lain: potensi banjir, angin kencang, abrasi pantai hingga tsunami (Ruswandi \& Saefuddin, 2008). Potensi bencana tersebut semakin meningkat bila tidak diikuti dengan ketanggapan terhadap kapan dan seberapa besar tingkat resiko yang akan dihadapi oleh komunitas yang ada di pesisir. Salah satu potensi bencana yang selalu terjadi di kawasan pesisir adalah genangan banjir (Hapsoro \& Buchari, 2015) dimana kawasan pesisir selalu mendapat kiriman air dari kawasan yang lebih tinggi di sekitarnya.

Banjir merupakan suatu kondisi ketika air masuk dan menggenangi kawasan kawasan rendah di sekitar sungai atau saluran yang diakibatkan oleh ketidakmampuan dalam mengalirkan dan menampung air (BNPB, 2012). Salah satu yang memicu terjadinya banjir adalah terjadinya alih fungsi lahan yang dahulunya kawasan hutan atau resapan menjadi lahan pertanian ataupun permukiman yang menyebabkan rusaknya daya serap air di lingkungan sekitar sehingga menggangu keseimbangan siklus dan kualitas air (Iskandar \& Sugandi, 2015). Alih fungsi lahan memberikan pengaruh yang lebih besar dari pada pembuatan bangunan pengendali banjir (Rosyidie, 2013). Kawasan yang banyak terdampak banjir adalah kawasan permukiman. Menurut Data dan Informasi Bencana Indonesia 2019, korban meninggal akibat banjir adalah sebanyak 289 jiwa sedangkan korban terdampak dan mengungsi akibat banjir adalah sebanyak 649,659 jiwa dan rumah yang terendam adalah sebanyak 94,591unit rumah. Hal tersebut menunjukkan bencana banjir memiliki dampak yang lebih besar dari jenis bencana lainnya. Terpicu dari bencana gempa dan tsunami yang terjadi di Samudera Hindia, konsep penanggulangan bencana mengalami pergeseran dari pengelolaan tanggap bencana (disaster response) ke arah pengurangan resiko bencana (disaster risk reduction). Konsep ini adalah perpaduan antara unsur teknis dan ilmiah dengan fokus kepada faktor ekonomi, sosial dan lingkungannya. Pendekatan ini menitikberatkan pada upaya peningkatan kapasitas masyarakat dalam menekan dan mengelola tekanan atau bencana yang akan terjadi. Disini masyarakat berperan sebagai subyek sekaligus obyek dan cenderung memperhatikan dan menggunakan local wisdom yang ada di masyarakat. Dalam pendekatan ini setiap orang yang ada di masyarakat akan dikenalkan dengan berbagai tekanan yang mengancam kawasan tersebut hingga diperkenalkan cara pengurangan kerentanan (vulnerability) dan ancaman (hazards) yang terjadi.

Tanjungpinang Barat merupakan kelurahan yang terletak di kawasan pesisir. Kawasan ini selalu menjadi tempat tumpuan air dan sampah kiriman sebelum sampai ke laut karena memiliki kontur yang lebih rendah dari daerah sekitarnya. Kondisi drainase yang buruk dan elevasi yang rendah menjadi penyebab utama terjadinya banjir di kawasan permukiman. Kampung kolam adalah salah satu daerah yang paling rawan dari bencana banjir di 
Tanjungpinang (M \& Ulfa, 2019). Banjir selalu terjadi ketika curah hujan yang tinggi dan diperparah dengan siklus pasang air laut yang telah mencapai ketinggian melebihi jalan raya. Ketinggian air di kawasan kampung kolam melebihi satu meter. Banyak masyarakat yang melakukan upaya adaptasi dengan memasang tanggul pada pintu masuk rumah, namun hal tersebut tidak begitu berpengaruh karena air tetap masuk melalui sela sela lantai rumah dan terjadi terus menerus. Kejadian tersebut banyak menimbulkan gangguan aktifitas sosial dan aktifitas ekonomi masyarakat (Arif, Giyarsih, \& Mardiatna, 2017). Adapun upaya penanggulangan yang dilakukan masih berupa kegiatan fisik yaitu dengan perbaikan drainase lingkungan dan peninggian jalan lingkungan. Namun genangan air tetap masuk ke dalam rumah dan mengakibatkan potensi kerugian yang tinggi. Hal tersebut terjadi secara terus menerus membuat masyarakat permukiman kampung kolam menjadi semakin rentan. Oleh karena itu diperlukan suatu pendekatan untuk mengetahui seberapa tinggi tingkat kerentanan yang terjadi di masyarakat sehingga dapat dilakukan upaya pengurangan resiko bencana yang terjadi di kemudian hari.

\subsection{Kerentanan Kawasan Permukiman}

Kerentanan merupakan karakteristik dari respon suatu sistem terhadap laju perubahan iklim dan variasi di mana suatu sistem memiliki keterpaparan, sensitivitas dan kapasitas adaptif dari sistem tersebut (IPCC, 2007). Kerentanan menurut BNPB (2012) adalah suatu kondisi dari suatu komunitas atau masyarakat yang mengarah atau menyebabkan ketidakmampuan dalam menghadapi ancaman bencana. Menurut Turner, Kasperson, and Matson (2003), kerentanan tidak hanya terjadi karena keterpaparan suatu bahaya saja, tetapi juga dipengaruhi sensitivitas serta ketahanan yang timbul dari pengalaman yang terjadi. Kemudian diperjelas oleh Adger (2006) yang mengatakan bahwa kerentanan dapat menjadi alat analisa dalam menggambarkan tingkat resiko terkena kerusakan dan ketidak berdayaan dari sistem fisik maupun sosial. Namun pola kerentanan selalu digambarkan negatif dalam keterpaparan terdampak bahaya. Di daerah pesisir dan pulau pulau kecil, terkadang memiliki jenis bahaya dan tingkat yang sama, namun karena letak dan ukuran goegrafis yang berbeda dapat menimbulkan kerusakan yang lebih parah dari pada daerah daratan yang luas sehingga membuat tingkat kerentanannya menjadi lebih tinggi (Sjo, 2017). Konsep kerentanan menurut IPCC (2001) dapat diperjelas dengan tingkat keterpaparan (Exposure), sensitivitas (Sensitivity), dan kapasitas adaptasi (Adaptive Capacity). Faktorfaktor yang mempengaruhi perkembangan permukiman menurut Siswono dalam Vacum et al. (2018) antara lain faktor geografi, kependudukan, kelembagaan, swadaya dan peran serta masyarakat, sosial dan budaya, ekonomi dan keterjangkauan daya beli, sarana dan prasarana, pertanahan, ilmu pengetahuan dan teknologi.

\subsubsection{Keterpaparan (Exposure)}

Keterpaparan merupakan ukuran yang menunjukkan sejauh mana suatu sistem bersentuhan dengan atau mengalami gangguan atau bahaya (Gallopın, 2006). Karakteristik faktor gangguan atau tekanan meliputi ketinggian banjir, frekuensi, durasi dan luas areal bahaya (Coulibaly et al., 2015). Keterpaparan yang berhubungan dengan potensi bahaya akibat perubahan iklim seperti banjir, badai, cuaca ekstrim akan dapat dianalisa dengan perubahannya pada jangka panjang maupun dalam variasi perubahan iklim termasuk frekwensi dan besarannya. Adapun komponen keterpaparan menurut Turner et al. (2003) antara lain individu, rumah tangga, flora dan fauna serta ekosistem yang ada di kawasan tersebut. Menurut Boer (2013), tingkat keterpaparan dapat di analisis melalui data kemiringan dan topografi untuk memberi gambaran tentang kondisi fisik dasar eksisting, sumber penghidupan dan permukiman dari daerah lokasi yang berpotensi bencana seperti banjir di cekungan, longsor pada daerah tebing, dan bahaya rob pada garis pantai. Untuk 
kejadian banjir, data frekwensi, ketinggian genangan, hingga lama genangan dapat menjadi parameter keterpaparan suatu kawasan.

\subsubsection{Sensitivitas (Sensitivity)}

Sensitivitas atau kepekaan adalah tingkat di mana suatu sistem dapat dipengaruhi, baik secara negatif atau menguntungkan, oleh rangsangan tekanan atau gangguan terkait iklim (IPCC, 2007). Pandangan Turner et al. (2003) dalam penelitiannya menyebutkan bahwa sensitivitas terdiri dari dua bagian yaitu, kondisi sensitivitas masyarakat yang mencakup modal sosial seperti populasi, struktur ekonomi, hingga kelembagaan yang ada di masyarakat dan kondisi sensitivitas lingkungan yang mencakup kondisi air, tanah, cuaca.

\subsubsection{Kapasitas Adaptasi (Adaptive Capacity)}

Kapasitas adaptif adalah kemampuan suatu sistem untuk menyesuaikan diri dengan perubahan iklim (termasuk variabilitas iklim dan ekstrem) untuk meminimalisir kerusakan potensial, untuk mengambil keuntungan dari peluang, atau untuk mengatasi konsekuensinya (IPCC, 2001). Adapun komponennya antara lain akses informasi, seperti tingkat pendidikan, tingkat pendapatan, rencana tanggap darurat, program konservasi hingga program kesehatan (Polsky \& Yarnal, 2007).

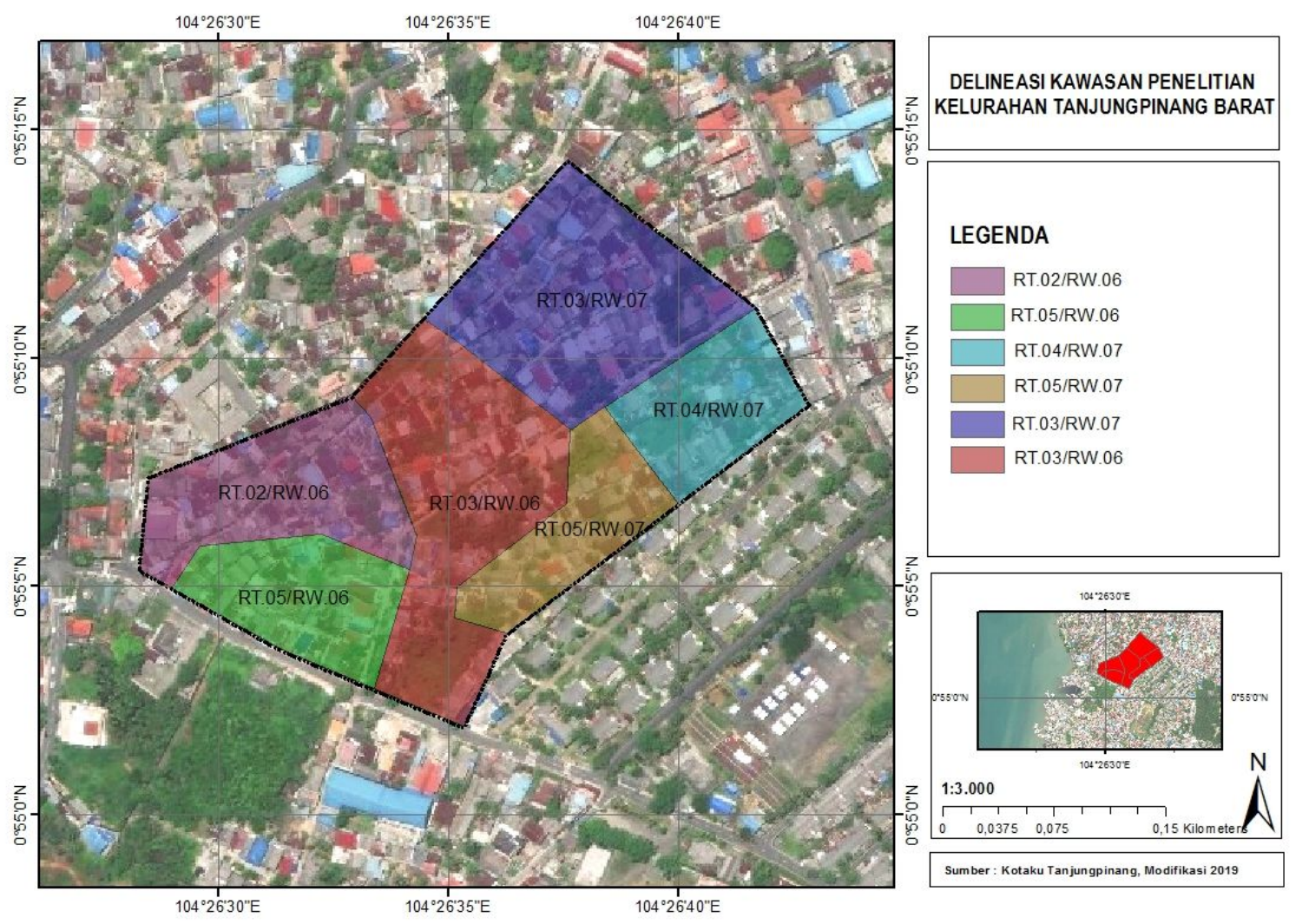

Gambar 1. Lokasi Kampung Kolam, Kelurahan Tanjungpinang Barat

\section{METODE PENELITIAN}

Adapun metode penelitian yang dilakukan pada penelitian ini adalah metode kuantitatif dengan mengelompokkan suatu komunitas dengan karakteristik wilayah dan batasan 
administrasi yang ada di masyarakat dengan skala mikro. Masing masing variabel kerentanan diuraikan berdasarkan komponen pembentuk kerentanan berdasarkan IPCC. Komponen variabel keterpaparan antara lain frekwensi banjir, ketinggian genangan air, lama waktu genangan air, kondisi drainase dan kondisi jalan lingkungan di kawasan tersebut. Untuk komponen sensitivitas terdiri dari jumlah anggota keluarga usia rentan, jenis rumah, status kepemilikan, jenis sumber air bersih, kelancaran air bersih, jumlah masyarakat yang sakit. Sedangkan untuk kapasitas adaptasi antara lain tingkat pendapatan, kemampuan masyarakat untuk menabung, tingkat pendidikan, dan kesadaran masyarakat untuk gotong royong. Adapun teknis pengumpulan data dilakukan dengan proportional random sampling dimana sebaran masing masing wilayah telah dibagi sesuai jumlah secara proporsional. Adapun pengambilan sampling $80 \mathrm{KK}$ berdasarkan perhitungan menggunakan rumus slovin dengan nilai signifikansi $10 \%$ dan dilakukan pada 398 KK yang kemudian dibagi menurut porsi jumlah KK pada tiap masing masing RT.

Tabel 1. Pola Distribusi Kuisioner

\begin{tabular}{|c|c|c|c|}
\hline \multicolumn{2}{|c|}{ Kawasan Penelitian } & \multirow[b]{2}{*}{$\begin{array}{l}\text { Jumlah } \\
\text { RT }\end{array}$} & \multirow{2}{*}{$\begin{array}{l}\text { Jumlah } \\
\text { Sample } \\
\text { (Kepala } \\
\text { Keluarga/ } \\
\text { Orang) } \\
\end{array}$} \\
\hline RW & RT & & \\
\hline 006 & 02 & 59 & 12 \\
\hline 006 & 03 & 71 & 14 \\
\hline 006 & 05 & 65 & 13 \\
\hline 007 & 03 & 71 & 14 \\
\hline 007 & 04 & 72 & 14 \\
\hline \multirow[t]{2}{*}{007} & 05 & 63 & 13 \\
\hline & & 398 & 80 \\
\hline
\end{tabular}

Analisis dilakukan dengan sistem skoring dimana terlebih dahulu diberikan pembobotan pada masing masing varibelnya. Skala pengukuran yang digunakan menggunakan likert dimana akan dikelompokkan menjadi lima tingkatan dimana nilai terkecil adalah -2 dan nilai terbesar adalah 2. Nilai yang didapat akan dikalikan dengan bobot masing masing variabel. Indeks Ketepaparan dan Sensitivitas (IKS) merupakan perkalian antara bobot dan skoring pada variabel yang dimilikinya. Sedangkan Indeks Kapasitas Adaptasi (IKA) adalah hasil perkalian bobot dan skoring variabelnya.

Tabel 2. Bobot Variabel Kerentanan dengan Peringkat

\begin{tabular}{lllll}
\hline $\begin{array}{l}\text { Komponen } \\
\text { Kerentanan }\end{array}$ & \multirow{2}{*}{ Aspek } & Variabel & $\begin{array}{l}\text { Peringka } \\
\mathbf{t}\end{array}$ & $\begin{array}{l}\text { Bobo } \\
\mathbf{t}\end{array}$ \\
\hline Keterpaparan & \multirow{2}{*}{ Fisik } & Frekwensi Banjir & 5 & $10 \%$ \\
\cline { 3 - 5 } & & Ketinggian & 5 & $10 \%$ \\
\cline { 3 - 5 } & & Lama Genangan & 5 & $10 \%$ \\
\cline { 2 - 5 } & Sosial, Budaya, & Kondisi Drainase Lingkungan & 5 & $10 \%$ \\
\cline { 2 - 5 } & Kelembagaan & Jumlah Anggota Keluarga & 3 & $6 \%$ \\
\hline \multirow{2}{*}{ Sensitivitas } & Fisik & Mata Pencaharian & 4 & $8 \%$ \\
& & Sumber Air Bersih & 4 & $8 \%$ \\
\cline { 3 - 5 } & & Pengelolaan Sampah & 3 & $6 \%$ \\
\cline { 3 - 5 } & & Jenis Rumah & 2 & $4 \%$ \\
\cline { 3 - 5 } & & &
\end{tabular}


Kerentanan Kawasan Permukiman Rawan Banjir Kampung Kolam Kelurahan Tanjungpinang Barat Tanjungpinang

\begin{tabular}{|c|c|c|c|c|}
\hline $\begin{array}{l}\text { Komponen } \\
\text { Kerentanan }\end{array}$ & Aspek & Variabel & $\begin{array}{l}\text { Peringka } \\
\mathrm{t}\end{array}$ & $\begin{array}{l}\text { Bobo } \\
t\end{array}$ \\
\hline & $\begin{array}{l}\text { Sosial, Budaya, } \\
\text { Kelembagaan }\end{array}$ & Rasio Usia Rentan & 5 & $10 \%$ \\
\hline & & Gender & 5 & $10 \%$ \\
\hline & Ekonomi & Jumlah Anggota Yang bekerja & 4 & $8 \%$ \\
\hline & & Total & 50 & $100 \%$ \\
\hline \multirow[t]{8}{*}{$\begin{array}{l}\text { Kapasitas } \\
\text { Adaptasi }\end{array}$} & Fisik & Rekayasa Teknologi & 4 & $17 \%$ \\
\hline & \multirow[t]{3}{*}{$\begin{array}{l}\text { Sosial, Budaya, } \\
\text { Kelembagaan }\end{array}$} & $\begin{array}{l}\text { Kesadaran dalam bergotong } \\
\text { royong }\end{array}$ & 4 & $17 \%$ \\
\hline & & Unsur Kelembagaan yang aktif & 2 & $8 \%$ \\
\hline & & Tingkat Pendidikan & 3 & $13 \%$ \\
\hline & \multirow[t]{4}{*}{ Ekonomi } & Tingkat Pendapatan & 3 & $13 \%$ \\
\hline & & Kemampuan untuk menabung & 5 & $21 \%$ \\
\hline & & $\begin{array}{ll}\text { Tingkat Kemahalan } & \text { Biaya } \\
\text { Renovasi Bangunan } & \\
\end{array}$ & 3 & $13 \%$ \\
\hline & & Total & 24 & $100 \%$ \\
\hline
\end{tabular}

Indeks Kerentanan merupakan kombinasi dari IKA dan IKS yang kemudian diposisikan pada diagram tipologi kerentanan. Dengan diketahui nya posisi masing masing variabel akan mejelaskan sejauh mana tingkat kerentanan dari kelompok masyarakat pada masing masing wilayah penelitian tersebut.

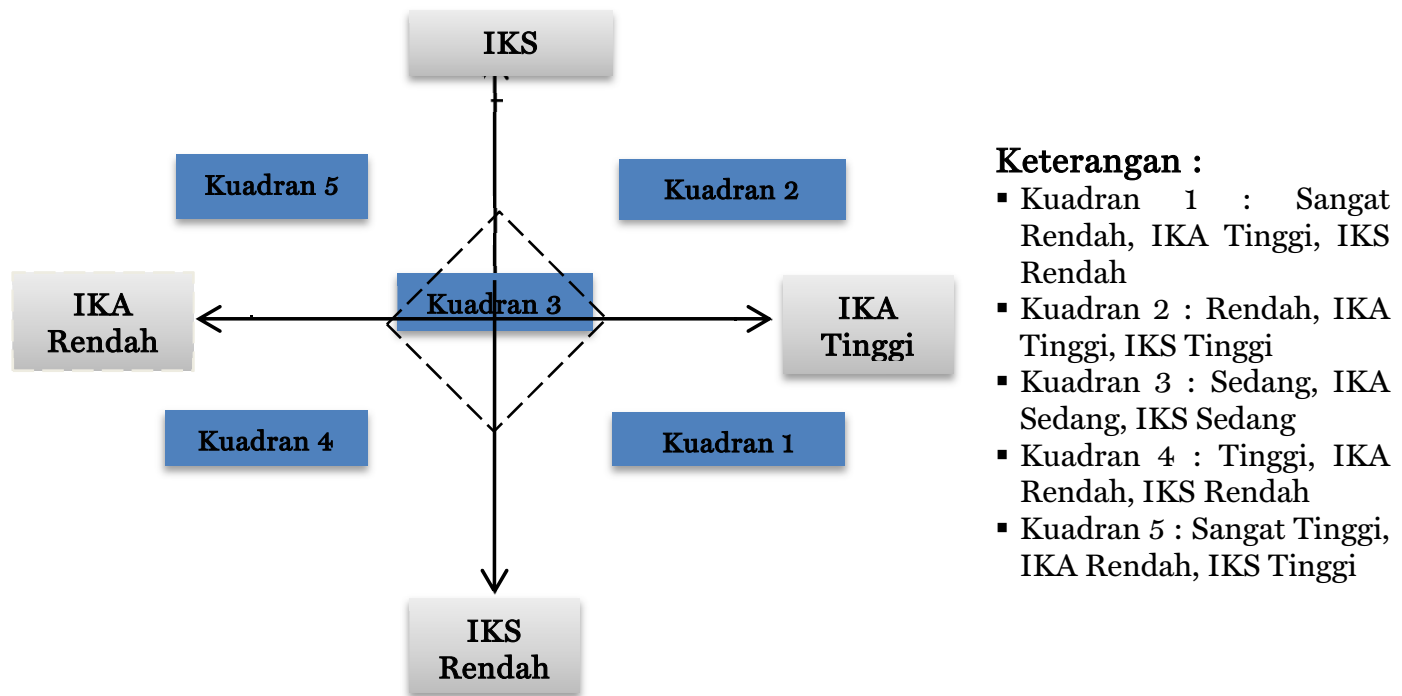

Gambar 2. Tipologi Kerentanan (Boer, 2013)

\section{HASIL DAN PEMBAHASAN}

Adapun hasil dari analisis yang telah dilakukan pada masyarakat Kampung Kolam menunjukkan adanya perbedaan tipologi kerentanan pada kawasan Kampung Kolam. Secara umum tipologi kerentanan masyarakat kampung kolam adalah memiliki tingkat kerentanan yang sangat tinggi, namun terdapat juga rumah tangga yang memiliki tipologi 
kerentanan yang sedang hingga kerentanan tinggi dan persebarannya memiliki variasi pada masing masing RT dan RW.

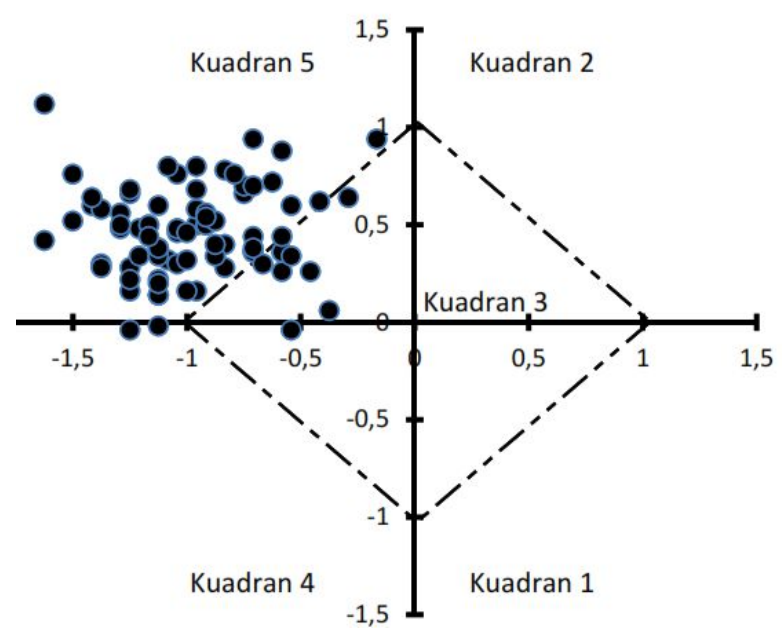

Gambar 3. Tipologi Kerentanan Masyarakat Kampung Kolam

Pola persebaran tipologi masing masing zonasi memiliki karakteristik yang berbeda. Pada Gambar.4 dapat disimpulkan bahwa wilayah RT.02/RW.06, kerentanan masyarakat sebagian besar berada pada kuadran 5 dengan pencaran data sebanyak 75,0\% memiliki kerentanan yang sangat tinggi. Sedangkan di kuadran 4 memiliki pencaran data sebanyak $8,33 \%$ dengan tingkat kerentanan tinggi serta terdapat $16,67 \%$ pada kuadran 3 dengan kerentanan sedang. persebaran kerentanan yang terjadi pada kuadran 5 terlihat lebih renggang yang mana memberikan gambaran bahwa masing masing rumah tangga memiliki karakteristik keterpaparan, sensitivitas dan kapasitas adaptasi yang cukup beragam meskipun berada dalam satu wilayah administrasi.
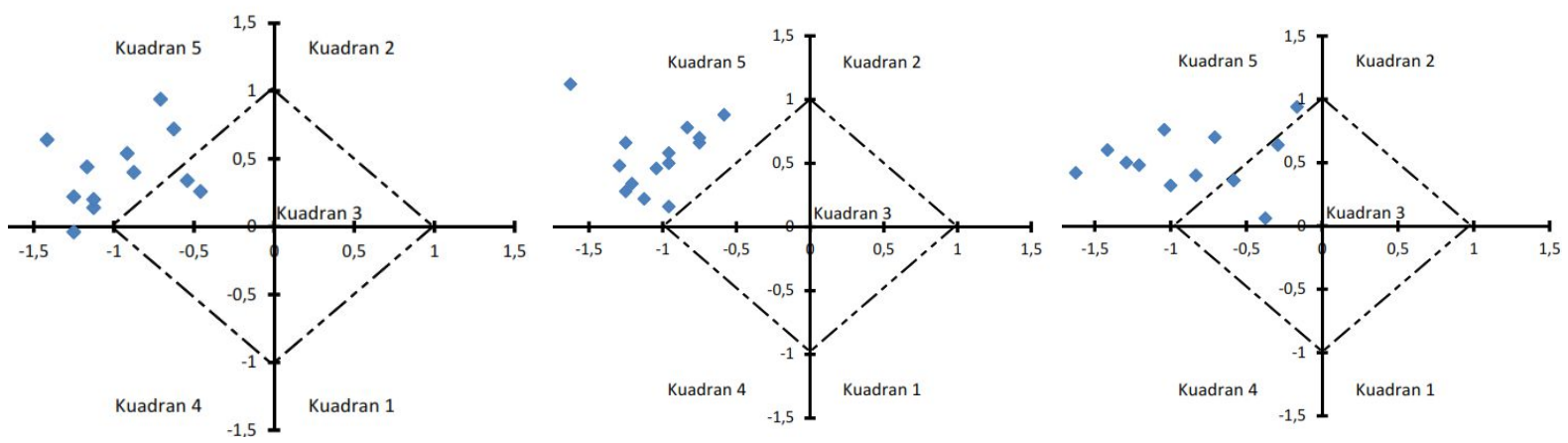

Gambar 4. Tipologi Kerentanan Masyarakat Kampung Kolam RT.02, RT.03, RT.05 / RW.06 (dari kiri ke kanan)

Selain itu dari gambar tipologi diatas menunjukkan bahwa wilayah RT.03/RW.06 memiliki kerentanan masyarakat seluruhnya berada pada kuadran 5 dengan pencaran data sebanyak 14 KK. Meskipun terdapat satu pencaran yang menjauh dari kelompok yang berdekatan, namun pola persebaran pencaran lainnya memiliki jarak yang lebih rapat dan berhimpitan. Hal tersebut memberikan gambaran tipologi kerentanan yang lebih memiliki hubungan yang lebih erat antara rumah tangga satu dengan rumah tangga lainnya. 
Tabel 3. Tipologi Kerentanan Banjir RW.06 Kampung Kolam

\begin{tabular}{lrrlllll}
\hline \multirow{2}{*}{ Kuadran } & \multicolumn{7}{l}{ Cluster RW.06 } \\
\cline { 2 - 8 } & & $\begin{array}{l}\text { RT.02/ } \\
\text { RW.06 } \%)\end{array}$ & \multicolumn{2}{l}{$\begin{array}{l}\text { RT.03/ RW.06 } \\
(\%)\end{array}$} & $\begin{array}{l}\text { RT.05/ } \\
\text { RW.06 }\end{array} \quad$ (\%) \\
\hline $\begin{array}{l}\text { Kuadran } \\
\text { Rentan) }\end{array}$ & I (Tidak & 0 & 0,00 & 0 & 0,00 & 0 & 0,00 \\
\hline $\begin{array}{l}\text { Kuadran } \\
\text { (Rendah) }\end{array}$ & II & 0 & 0,00 & 0 & 0,00 & 0 & 0,00 \\
\hline $\begin{array}{l}\text { Kuadran } \\
\text { (Sedang) }\end{array}$ & III & 2 & 16,67 & 0 & 0,00 & 3 & 23,08 \\
\hline Kuadran IV (Tinggi) & 1 & 8,33 & 0 & 0,00 & 0 & 0,00 \\
\hline $\begin{array}{l}\text { Kuadran V (Sangat } \\
\text { Tinggi) }\end{array}$ & 9 & 75,00 & 14 & 100,00 & 10 & 76,92 \\
\hline Total & 12 & 100,00 & 14 & 100,00 & 13 & 100,00 \\
\hline
\end{tabular}

Pada wilayah RT.05/RW.06, kerentanan masyarakat bersifat lebih tersebar dan dinamis. Terdapat 76,92\% pencaran rumah tangga yang memiliki tingkat kerentanan sangat tinggi dan sebanyak $23,08 \%$ pencaran rumah tangga memiliki kerentanan sedang. Pola persebaran pada kuadran lima memiliki jarak yang cukup jauh menunjukkan tingkat perbedaan karakteristik kerentanan rumah tangga cukup bervariasi.
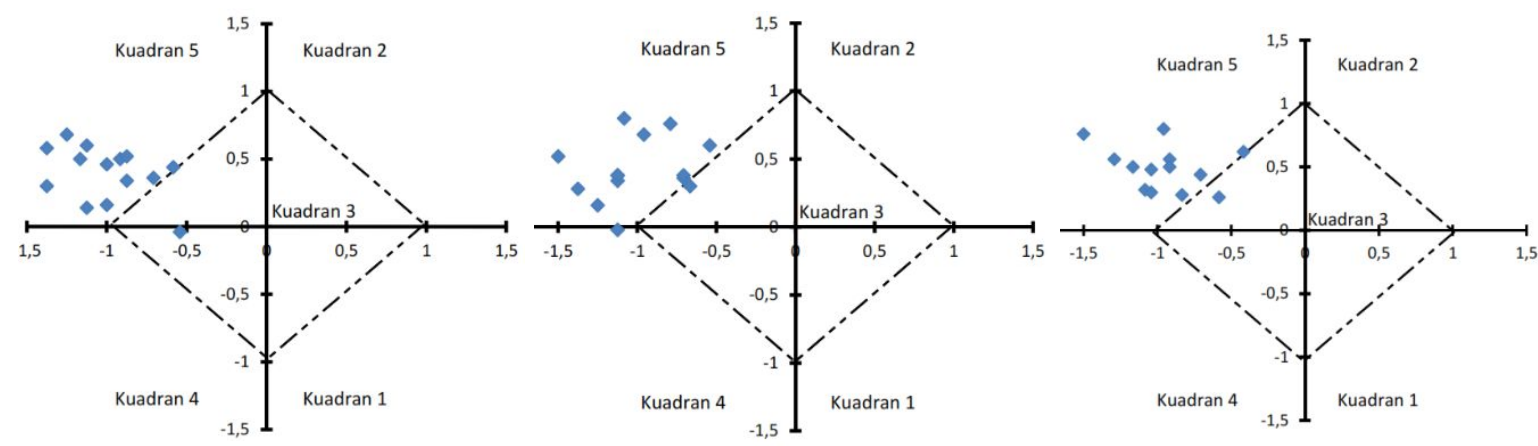

Gambar 5. Tipologi Kerentanan Masyarakat Kampung Kolam RT.03, RT.04, RT.05/ RW.07 (dari kiri ke kanan)

Berdasarkan gambar diatas, zonasi RT.03/RW.07 kerentanan masyarakat 92,86\% rumah tangga berada pada kuadran 5 dengan pencaran data sebanyak $13 \mathrm{KK}$. Selain itu terdapat $7,14 \%$ rumah tangga yang memiliki kerentanan sedang. Pola persebaran kerentanan cenderung bergerombol dengan jarak yang hampir berhimpitan. Hal tersebut menggambarkan bahwa karakteristik kerentanan rumah tangga cenderung memiliki kesamaan dan berdekatan serta memiliki hubungan yang lebih erat antara rumah tangga satu dengan rumah tangga lainnya. Sedangkan pada zonasi RT.04/RW.07, 78,57\% rumah tangga memiliki kerentanan yang sangat tinggi, sebanyak 7,14\% rumah tangga memiliki kerentanan tinggi dan 14,29\% rumah tangga memiliki kerentanan sedang. Meski demikian pada wilayah ini pola persebaran data kerentanan memiliki jarak yang cukup besar yang mana kerentanan rumah tangga nya memiliki perbedaan yang cukup terlihat. Hal tersebut menggambarkan bahwa wilayah ini memiliki karakteristik kerentanan rumah tangga yang tidak seragam. 
Tabel 4. Tipologi Kerentanan Banjir RW.07 Kampung Kolam

\begin{tabular}{ccccccc}
\hline \multirow{2}{*}{ Kuadran } & \multicolumn{5}{c}{ Cluster RW.07 } \\
\cline { 2 - 7 } & $\begin{array}{c}\text { RT.03/ } \\
\text { RW.07 (\%) }\end{array}$ & \multicolumn{2}{c}{$\begin{array}{c}\text { RT.04/ } \\
\text { RW.07 (\%) }\end{array}$} & $\begin{array}{c}\text { RT.05/ } \\
\text { RW.07 (\%) }\end{array}$ \\
\hline $\begin{array}{c}\text { Kuadran I (Tidak } \\
\text { Rentan) }\end{array}$ & 0 & 0,00 & 0 & 0,00 & 0 & 0,00 \\
\hline $\begin{array}{c}\text { Kuadran II } \\
\text { (Rendah) }\end{array}$ & 0 & 0,00 & 0 & 0,00 & 0 & 0,00 \\
\hline $\begin{array}{c}\text { Kuadran III } \\
\text { (Sedang) }\end{array}$ & 1 & 7,14 & 2 & 14,29 & 1 & 7,69 \\
\hline Kuadran IV (Tinggi) & 0 & 0,00 & 1 & 7,14 & 0 & 0,00 \\
\hline $\begin{array}{c}\text { Kuadran V (Sangat } \\
\text { Tinggi) }\end{array}$ & 13 & 92,86 & 11 & 78,57 & 12 & 92,31 \\
\hline Total & 14 & 100,00 & 14 & 100,00 & 13 & 100,00 \\
\hline
\end{tabular}

Gambar 5 juga menerangkan bahwa pada wilayah RT.05/RW.07, kerentanan masyarakat lebih bersifat bergerombol dengan $92,31 \%$ pencaran data memiliki tingkat kerentanan yang sangat tinggi dan sebanyak 7,69\% rumah tangga memiliki tingkat kerentanan sedang. Pola yang bergerombol memunjukkan ikatan dan hubungan kerentanan antar rumah tangga memiliki kedekatan yang tinggi.

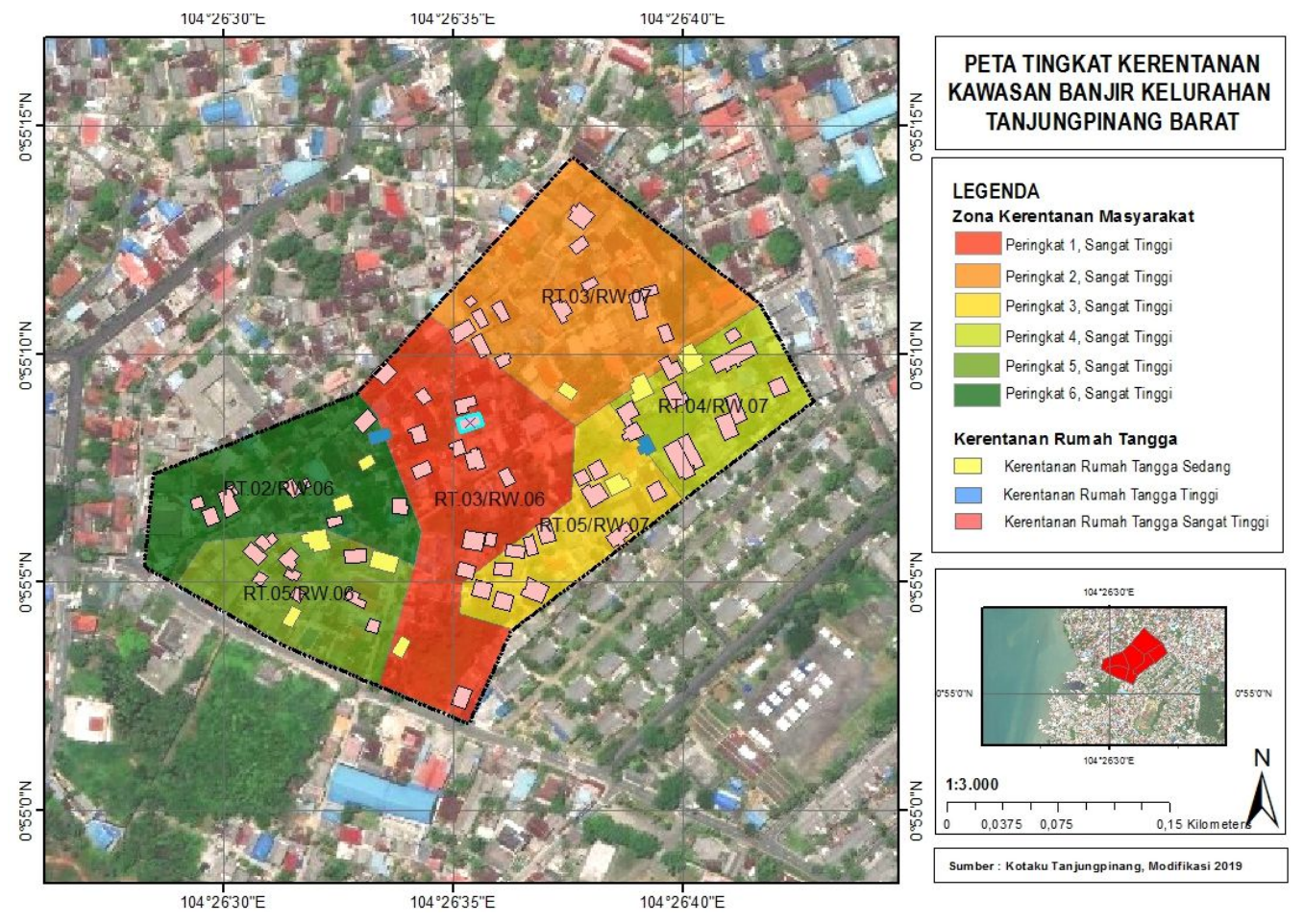

Gambar 6. Tingkat Kerentanan Kawasan Permukiman

Adapun variabel yang sangat mempengaruhi keterpaparan dan sensitivitas rumah tangga di kawasan banjir ini adalah tinggi genangan, lama genangan, frekwensi banjir, kondisi sistem drainase, status keterikatan mata pencarian, sistem pengelolaan sampah permukiman, jumlah anggota perempuan dan jumlah anggota yang bekerja. Sedangkan untuk variabel kapasitas adaptasi yang memiliki pengaruh tinggi adalah tingkat pendidikan, tingkat kesadaran untuk gotong royong masyarakat, sistem peringatan banjir, jumlah anggota perempuan 


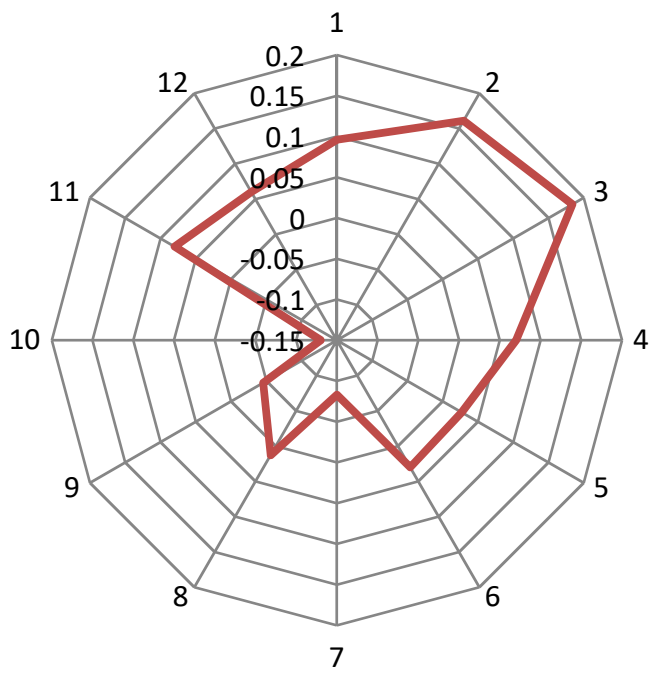

1. Frekwensi banjir

2. Ketinggian air

3. Lama genangan

4. Kondisi drainase

5. Jumlah Anggota Keluarga

6. Jenis Keterikatan Mata Pencaharian

7. Jenis penggunaan air bersih

8. Pengelolaan Sampah

9. Jenis rumah

10. Rasio Usia Rentan

11. Jumlah anggota keluarga perempuan

12. Jumlah anggota yang bekerja

Gambar 7. Faktor yang Berpengaruh pada Keterpaparan dan Sensitifitas

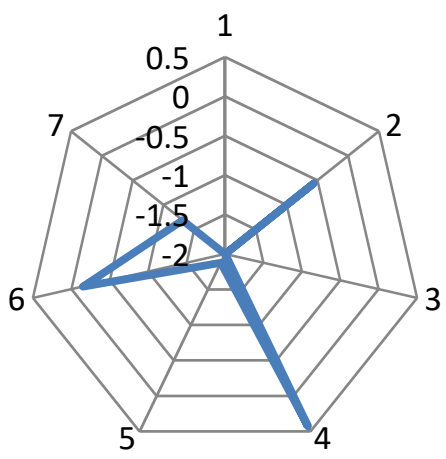

1. Rekayasa Teknologi peringatan banjir

2. Kesadaran gotong royong

3. Kelembagaan yang aktif

4. Tingkat Pendidikan

5. Kemampuan masyarakat untuk menabung

6. Tingkat pendapatan

7. Keterjangkauan biaya renovasi

Gambar 8. Faktor yang Berpengaruh pada Kapasitas Adaptasi Masyarakat

Dari hasil temuan diatas dapat diketahui bahwa masyarakat di kawasan kampung kolam memiliki kerentanan yang sangat tinggi. Pola penyebaran tingkat kerentanan lebih bersifat merata pada setiap RT, meskipun juga terdapat beberapa keluarga yang memiliki kerentanan sedang.Hal tersebut terjadi karena secara fisik kawasan ini memiliki kesamaan pada frekwensi banjir, lama genangan dan kondisi drainase yang kurang baik. Adapun yang menyebabkan perbedaan tingkat kerentanan antara lain status mata pencarian, jumlah anggota perempuan dan jumlah anggota yang bekerja. Masing masing keluarga memiliki komposisi yang berbeda menyebabkan pola persebaran kerentanan sedikit berbeda. Faktor yang memperkuat kapasitas adaptasi kawasan adalah kesadaran masyarakat untuk bergotong royong, namun karena kondisi kontur yang lebih rendah dari kawasan sekelilingnya membuat kegiatan tersebut tidak begitu mempengaruhi kondisi lingkungan.

Meskipun berada pada kondisi sangat rentan masyarakat cenderung memilih bertahan karena beberapa faktor antara lain tingkat pendidikan yang tinggi dan tingkat pendapatan. 
Tingkat pendidikan membuat masyarakat lebih adaptif dengan berbagai tekanan yang ada dan tingkat pendapatan yang cukup memberikan suatu kekuatan tersendiri bagi masyarakat untuk tetap tinggal dengan menggunakan keterampilan dan pengetahuan tentang bagaimana untuk terus dapat bertahan.

Penanganan dengan pendekatan adaptasi dapat dilakukan peningkatan kapasitas komunitas maupun individu dalam penguatan perekonomian dan pendapatan, pendidikan, kelembagaan yang aktif hingga pengembangan sistem peringatan banjir skala kawasan. Pola penanganan dengan pendekatan mitigasi berpedoman pada Permen PUPR No.2 Tahun 2016 tentang Peningkatan Kualitas Terhadap Perumahan Kumuh Dan Permukiman Kumuh yaitu dengan pemugaran dan peremajaan kawasan. Penanganan kawasan permukiman dibagi berdasarkan peringkat kerentanan setiap kawasan dimana dilakukan peremajaan pada kawasan permukiman dengan kerentanan tertinggi yang berada pada RT.03/RW.06 dan RT.05/RW.07, sedangkan pemugaran dilakukan pada kawasan RT.02/RW.06, RT.05/RW.06, RT.03/RW.07, RT.04/RW.07.

\section{KESIMPULAN}

Banjir merupakan suatu rutinitas yang selalu terjadi di kawasan Kampung Kolam. Kejadian ini dipicu kondisi geografis yang cenderung lebih rendah dari daerah sekitarnya. Hal tersebut diperparah oleh kiriman air dan sampah dari kawasan Bukit Cermin. Kondisi ini membuat masyarakat Kampung Kolam memiliki kerentanan yang sangat tinggi. Sebanyak $86,25 \%$ dari total responden memiliki kerentanan yang sangat tinggi, 2,50\% dari total responden berada pada tingkat kerentanan tinggi dan $11,25 \%$ dari total responden memiliki tingkat kerentanan sedang. Dari hasil persentase menunjukkan bahwa masyarakat telah memiliki ketahanan dalam menghadapi banjir meskipun sebagian besar berada dalam kerentanan yang tinggi.

Faktor yang sangat mempengaruhi kerentanan di kawasan ini antara lain tinggi genangan, lama genangan, frekwensi banjir, kondisi sistem drainase, status keterikatan mata pencarian, sistem pengelolaan sampah permukiman, jumlah anggota perempuan dan jumlah anggota yang bekerja, tingkat pendidikan, tingkat kesadaran untuk gotong royong masyarakat, sistem peringatan banjir, jumlah anggota perempuan di rumah tangga. Penilaian yang dilakukan tanpa memperhatikan perbedaan kerentanan siang dan malam, dan hanya dilakukan pada kondisi anggota keluarga berada di rumah. Rekomendasi penanganan kawasan dengan pendekatan mitigasi yang direkomendasikan antara lain peremajaan kawasan permukiman dilakukan pada kawasan dengan kerentanan tertinggi yaitu berada pada RT.03/RW.06 dan RT.05/RW.07, sedangkan pemugaran dilakukan pada kawasan RT.02/RW.06, RT.05/RW.06, RT.03/RW.07, RT.04/RW.07. Rekomendasi penanganan kawasan dengan pendekatan adaptasi yaitu peningkatan kapasitas komunitas maupun individu dalam penguatan perekonomian dan pendapatan, pendidikan, kelembagaan yang aktif hingga pengembangan sistem peringatan banjir skala kawasan.

Adapun penilaian kerentanan ini diharapkan dapat menjadi pertimbangan bagi pemangku kepentingan, sehingga pengambilan keputusan terkait penanganan bencana baik secara adaptasi ataupun mitigasi dapat dilakukan secara tepat, arif dan bijaksana.

\section{UCAPAN TERIMAKASIH}

Terimakasih kami berikan kepada berbagai pihak yang turut membantu penelitian baik ketika di lapangan maupun ketika penyusunan. 


\section{DAFTAR PUSTAKA}

Adger, W. N. (2006). Vulnerability. Global Environmental Change, 16, 268-281. doi:https://doi.org/10.1016/j.gloenvcha.2006.02.006

Arif, D. A., Giyarsih, S. R., \& Mardiatna, D. (2017). Kerentanan Masyarakat Perkotaan terhadap Bahaya Banjir di Kelurahan Legok, Kecamatan Telanipura, Kota Jambi. Majalah Geografi Indonesia, 31(2), 79. doi:https://doi.org/10.22146/mgi.29779

Peraturan Kepala Badan Nasional Penanggulangan Bencana Nomor 02 Tahun 2012 Tentang Pedoman Umum Pengkajian Resiko Bencana, (2012).

Boer, R. (2013). Rencana Aksi Mitigasi dan Adaptasi Perubahan Iklim dalam Kerangka Pengelolaan Sumber Daya Air DAS Citarum Kabupaten Bandung Barat (Vol. 53). Bandung Barat: BPLH Kabupaten Bandung Barat.

Coulibaly, J. Y., Mbow, C., Sileshi, G. W., Beedy, T., Kundhlande, G., \& Musau, J. (2015). Mapping Vulnerability to Climate Change in Malawi: Spatial and Social Differentiation in the Shire River Basin. American Journal of Climate Change, 4(3), 282-294. doi:https://doi.org/10.4236/ajcc.2015.43023

Diposaptono, S. (2003). Mitigasi Bencana Alam di Wilayah Pesisir dalam Kerangka Pengelolaan Wilayah Pesisir Terpadu di Indonesia. Alami: Jurnal Teknologi Reduksi Risiko Bencana, 8(2).

Gallopın, G. C. (2006). Linkages between vulnerability , resilience, and adaptive capacity. 16, 293303. doi:https://doi.org/10.1016/j.gloenvcha.2006.02.004

Ghozali, A., Ariyaningsih, Sukmara, R. B., \& Aulia, B. U. (2016). A Comparative Study of Climate Change Mitigation and Adaptation on Flood Management between Ayutthaya City (Thailand) and Samarinda City (Indonesia). Procedia - Social and Behavioral Sciences, 227, 424-429. doi:https://doi.org/10.1016/j.sbspro.2016.06.096

Hapsari, K., Rustiadi, E., \& Yulianda, F. (2017). Pengembangan Wilayah Pesisir Pantai Utara Jawa tengah Berdasarkan Infrastruktur Daerah: Studi Kasus Kabupaten Jepara. Journal of Regional and Rural Development Planning, 1(2), 145-157. Retrieved from http://mail.student.ipb.ac.id/index.php/p2wd/article/view/17390/12530.

Hapsoro, A., \& Buchari, I. (2015). Kajian Kerentanan Sosial Dan Ekonomi Terhadap Bencana Banjir (Studi Kasus: Wilayah Pesisir Kota Pekalongan). Teknik PWK (Perencanaan Wilayah Kota), 4(4), 542-553.

IPCC. (2001). A Report of Working Group II of the Intergovernmental Panel on Climate Change. Retrieved from

IPCC. (2007). Report of the Intergovernmental Panel on Climate Change. Retrieved from

Iskandar, D., \& Sugandi, D. (2015). Flood mitigation efforts in the Capital Region of Jakarta. International Journal of Conservation Science, 6(4), 685-696.

M, Y., \& Ulfa, H. (2019). Sosialisasi dan Pelatihan Teknis Pembuatan Lubang Resapan Biopori sebagai Solusi Pencegahan dan Penanganan Banjir di Kota Tanjungpinang. Jurnal Pengabdian Masyarakat, 1(2), 168-174.

Polsky, C. D., \& Yarnal, B. (2007). Building comparable global change vulnerability assessments : The Vulnerability Scoping Diagram. doi:https://doi.org/10.1016/j.gloenvcha.2007.01.005

Rosyidie, A. (2013). Banjir: Fakta dan Dampaknya, Serta Pengaruh dari Perubahan Guna Lahan. Journal of Regional and City Planning, 24(3), 241-249.

Ruswandi, R., \& Saefuddin, A. (2008). Identifikasi Potensi Bencana Alam dan Upaya Mitigasi yang Paling Sesuai Diterapkan di Pesisir Indramayu dan Ciamis. Jurnal RISET Geologi Dan Pertambangan, 18(2), 1. doi:https://doi.org/10.14203/risetgeotam2008.v18.12

Sjo, M. (2017). Vulnerability of Small Island Developing States to Natural Disasters : How Much Difference Can Effective Governments Make? Journal of Environment \& Development. doi:https://doi.org/10.1177/1070496516682339

Sulistyanto, I. (2017). Peran Pembangunan Permukiman Pesisir Dan Pulau-Pulau Kecil Sebagai Upaya Strategis Dalam Peningkatan Eksistensi Kedaulatan Maritim Indonesia. Teknik Sipil Dan Arsitektur, 20(24).

Turner, L., Kasperson, R. E., \& Matson, P. A. (2003). A framework for vulnerability analysis in sustainability science. doi:https://doi.org/10.1073/pnas.1231335100 
Vacum, J., Randa, M., Witjaksono, A., Setiyawan, A., Bendungan, J., \& Malang, S. N. (2018). Kajian Proses Perkembangan Permukiman di Kampung Ujoh Bilang, Kabupaten Mahakam Hulu Tahun 1950 Hingga 2018.

Yulia, A. (2014). Identifikasi Dampak Perubahan Fungsi Ekosistem Pesisir Terhadap Lingkungan di Wilayah Pesisir Kecamatan Muara Gembong. Jurnal Perencanaan Wilayah Dan Kota, 14(1), 1-13. 